Lesya Kononenko, Associate Professor, PhD of Economics (Candidate of Economic Sciences) Central Ukrainian National Technical University, Kropyvnytskyi, Ukraine Serhii Kononenko, Associate Professor, $\mathrm{PhD}$ in Pedagogy (Candidate of Pedagogy Sciences) Volodymyr Vynnychenko Central Ukrainian State Pedagogical University, Kropyvnytskyi, Ukraine Valerii Mytsenko, Associate Professor, PhD of Pedagogy (Candidate of Pedagogy Sciences) Central Ukrainian National Technical University, Kropyvnytskyi, Ukraine

\title{
Formation of Professional Knowledge among Graduates of Higher Educational Institutions in the Conditions of Knowledge-Based Economy: Integrative Approach
}

The possibilities of using an integrative approach in the process of forming professional knowledge among graduates of higher educational institutions were studied in the article. The categories "information" and "knowledge" have been considered. It is suggested to consider information as a "raw material" for the formation of knowledge, and knowledge as a "quality" that is inherent in a particular individual. It is stated that knowledge is constantly transformed into information and vice versa. It has been determined that the application of an integrative approach has a positive impact on the formation of professional knowledge among university graduates.

information, knowledge, professional knowledge, knowledge economy, integration, integrative approach, educational institutions, graduates of higher educational institutions

Л.В. Кононенко, доц., канд. экон. наук

Центральноукраинский нацииональный технический университет, г. Кропивницкий, Украина

С.А. Кононенко, доц., канд. пед. наук.

Центральноукраинский государственный педагогический университет имени Владимира Винниченко,

2. Кропивницякий, Украина

В.И. Мыценко, доц., канд. пед. наук.

Центральноукраинский национальный технический университет, г. Кропивниикий, Украина

Формирование профессиональных знаний у выпускников высших учебных заведений в условиях экономики знаний: интегративный подход

В статье исследованы возможности использования интегративного подхода в процессе формирования профессиональных знаний выпускников высших учебных заведений. Рассмотрены категории «информация» и «знание». Предложено рассматривать информацию как «сырье» для формирования знаний, а знания - как «качество», которое присуще определенному индивидууму. Отмечено, что постоянно происходит трансформация знания в информацию и наоборот. Определено, что использование интегративного подхода имеет положительное влияние на формирование профессиональных знаний у выпускников высших учебных заведений.

информация, знание, профессинальные знания, экономика знаний, интеграция, интегративный подход, учебные заведения, выпускники.

Statement of the problem. Modern society is characterized by the processes of globalization and integration of political, economic and cultural life all over the world. This applies in particular to education which is based on a problematic approach to the content of professional training. This necessitates the development of the ability of a modern graduate to solve complex tasks that usually arise in the process of professional activity. When integrated knowledge is applied, ordinary information is transformed into the method of solving professional problems.

The relevance of the study is primarily due to the fact that in a market economy, labour is commodity and, like any commodity, it is subject to sale (lease). It is well known that any market

(C) Lesya Kononenko, Serhii Kononenko, Valerii Mytsenko, 2019 
entity seeks maximum profit. A person is also a business entity that seeks to sell (rent) as their most expensive work. At the same time, today the employer lays down high enough requirements to the quality of this work. In addition, modern society is characterized by permanent changes that occur in all spheres of activity, which necessitates lifelong learning.

So, the ability to make independent decisions, the ability to think, and the ability to solve complex interdisciplinary problems in non-standard situations become essential. Therefore, a graduate of a higher educational institution must, first of all, think and be able to use the information (knowledge in its higher form) that it has received. Thus, Alexander Dumas noted that "knowledge produces knowledge, and the ability to think produces thinking" [9]. Having only a narrow professional background significantly reduces the individual's ability to adapt.

Analysis of recent researches and publications. The issues of the formation of professional knowledge were investigated by foreign and national scientists. Thus, Yu. Kozlovskyi studied the peculiarities of forming professional knowledge of future computer-engineering teachers [4]. The works of N.O. Podluzha are devoted to the substantive content and problems of information support of knowledge economy formation in Ukraine [6], V.M. Dzhulii considered the model of formation of goals for information support of knowledge-supporting processes [2], and T.G. Busareva considered specific features of the formation of the world market of knowledge [1].

Modern scholars say $[2 ; 4 ; 6]$ that there is a close relationship between the level of professional excellence of a university graduate (potential employee) and the degree of integration of his or her basic knowledge. The essence of the integration is that the integrated knowledge is more capacious and compact, closer to professional problematic knowledge.

However, the process of the formation of professional knowledge among university graduates in the context of knowledge economy according to integrative approach has not been thoroughly studied. Thus, a university graduate in his/her professional activity faces a variety of problems that are part of the object of professional activity, while in the learning process the main attention is focused on the acquiring basic scientific and domain knowledge. One of the ways to optimize the training of future professionals is to apply an integrative approach to the formation of professional knowledge.

Statement of the objective. The objective the article is to substantiate the feasibility of forming professional knowledge of university graduates in the knowledge economy according to the integrative approach.

The main material. In the conditions of knowledge economy, knowledge becomes a separate significant economic resource along with labour, land, capital and entrepreneurial skills.

Even A. Smith highlighted the role of knowledge. He stated that in some activities the division of labour is stronger than in others. K. Marx studied the category of "knowledge" in connection with the reproduction of fixed capital, and he noted that "the development of fixed capital is an indicator of the extent to which public knowledge is transformed into direct productive power." A. Marshall stated that "a large part of capital is knowledge ... Knowledge is our most powerful engine of production". He also considered knowledge as a necessary factor in entrepreneurial activity. K. Menger considered knowledge as the most important factor of economic progress. J. Schumpeter, F. Hayek, and G. Simon stated that knowledge is a necessary condition and driving force for economic development. S. Kuznets noted that the basis of modern economic growth is useful knowledge and expansion of the areas of its application. Academician V. Makarov noted that "knowledge production is a source of economic growth". P. Drucker as early as the mid-1950s considered knowledge as a major business resource. E. Toffler said that knowledge has a strong creative potential and, taking 
into consideration the existing trends that are observed in the struggle for information possession, may well replace material resources [5, p. 47].

In our opinion, knowledge can be equated with material resources, but the possibility to "completely replace them with self" is controversial.

Education is the basis for the formation of knowledge. Education facilitates the formation of viewpoints and provides adjustment of professional abilities of the population. However, educational institutions provide students with "information" which, in the process of obtaining education, should be transformed into "knowledge". It should be noted that today there is no consensus among scholars about the identity of these categories. In our opinion, the categories of "information" and "knowledge" are somewhat different. Thus, T.G. Busareva truly states that the main difference between knowledge and information is the degree of organization and awareness of the primary data [1]. However, we believe that the main difference lies not only in the degree of organization and awareness of the primary data, but also in their orientation. Truly, information is a "raw material" for knowledge formation, a basic resource, a service, and therefore a product. This product is on the market and, like any other product, is subject to purchase and sale (or free transfer). Knowledge, in our view, is systematic, structured information possessed by an individual. That is, knowledge is the quality of the individual. However, there is constant transformation of knowledge into information and vice versa: information - knowledge - information (Fig. 1).

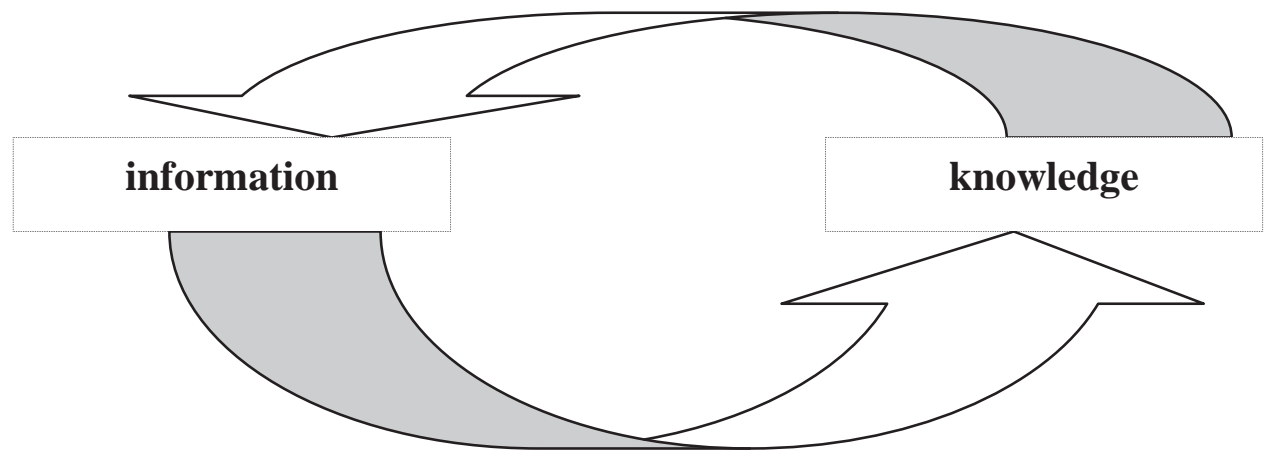

Figure 1 - Transformation of knowledge into information and vice versa Source: created by the authors.

Information meets the need of a certain subject, generates new knowledge in an individual on the basis of which he or she creates and transmits (sells) new (or receives) information. There is constant and continuous process of transformation between information and knowledge

In today's context, knowledge formation takes place at educational institutions through education. Nowadays, professional education is of increasing importance. It becomes a prerequisite and basis for science and an efficient performance of various entities, institutions and organizations. Graduates make current offers in the labour market. At the same time, the basis of their competitiveness is the knowledge acquired during training and the ability to use it in their activity. In addition, it should be noted that current scientific trends are characterized by the objective processes of differentiation and integration.

The development and formation of the knowledge economy implies the existence of a single information base, which necessitates the coherence of terminology in different scientific segments of a single information space. At the initial stages of the development of socio-economic relations, the differentiation of knowledge did not occur, that is, there were no differences in terminology (because terminology did not exist at all). Later, there was a 
differentiated development of various scientific fields, which was carried out within the narrow special professional purpose. That was quite logical and appropriate at a certain stage of development of sciences and socio-economic relations. At present stage of society's development there is an integration of different sectors of knowledge on the basis of primary information. However, their merger is not observed because each of them continues to perform their functions and resolve their issues. But, historically, in the process of developing different areas of knowledge, they have already created specific terminology. In addition, quite often, the same term in different scientific sectors has different meanings.

Modern scientific segments are characterized by considerable uncertainty in terminology. In addition, parallel terminology is often and unreasonably used. Thus, in macro- and microeconomics there are terms "means of production" and "objects of production", and in accounting these terms correspond to "fixed assets" and "materials". Labour cooperation and deepening of accounting functions also led to different terminology according to different purposes of application, for example, "fixed assets", "fixed funds". The precondition for the problems related to differentiating the accounting system and distinguishing its constituent component such as management accounting is also the inconsistency of the use of terms. In addition, processes of globalization lead to the use of translated terminology. In this case, borrowings of certain terms also become a problem, which consists in impossibility of a completely identical translation. Terms have different meaningful colourings in different languages. Therefore, it is necessary to provide each scientific segment with appropriate terminological apparatus that would be consistent with other scientific segments.

Universal terminological apparatus will allow providing the information which optimizes the formation of integrated knowledge among students. It should be noted that $\mathrm{Yu}$. Kozlovskyi states that "quantitative accumulation of homogeneous elements does not allow achieving new quality in professional training, so the elements of integration must be heterogeneous enough to prevent their merging ... When elements of integration begin to interact, the effectiveness of the interaction increases to a certain value. Conditionally, this phenomenon can be called saturation, because the subsequent connection of new elements no longer affects the state of the integrated object" [4]. He notes that integration is the only process of interaction of elements, which simultaneously ensures the systematic end result of the process and preserves individual properties of the elements of integration. This combination of integration features makes it possible to have several stable states of the integrated object, which is especially important in the formation of professional knowledge. It is the preservation of individual properties of the elements of integrated knowledge that allows structuring knowledge according to both subject and problem principles. Taking into account that the dependencies between the parameters of the integrated system are nonlinear, the amount of integrated knowledge is less than the amount of information that is integrated due to the qualitative element transformations.

The methodology of integration in learning process provides the conditions under which teaching is based not only on the transfer of prepared information, but also on the acquisition of certain skills by a student through solving theoretical and practical problems. Thus, in the formation of knowledge, we use the bases of enterprises (organizations, institutions), where students have the opportunity to apply the knowledge, formed at the university, in practice. Such training develops students' abilities and creativity; promotes motivation for learning and harmonization of the educational process; fosters independence and activity. In addition, this approach focuses students' attention not only on theoretical material of the foundations of science or the field of knowledge, but also on a specific practical task or problem. 
Conclusions and prospects for further researches. Education is the basis for knowledge. In the learning process, educational institutions provide students with "information" that in the course of learning is transformed into "knowledge". This "knowledge" changes an individual who begins to acquire it. The process of acquiring knowledge in higher education is quite complex. It is the integrative approach to the process of formation of professional knowledge that will allow a graduate of a higher education institution to have competitive advantages in the labour market in the knowledge-based economy. In addition, the generated integrated knowledge allows university graduates to update both the acquired knowledge and to form new ones throughout his/her life. The prospects for further research in this area are related to the construction of the system of knowledge parameters and their relations in order to take a holistic approach to the formation of professional competencies of university graduates.

\section{Список літератури}

1. Бусарєва Т. Г. Специфічні риси формування світового ринку знань. Науковий вісник Херсонського державного університету. Сер. : Економічні науки. 2019. Вип. 34. С. 7-12. URL: http://nbuv.gov.ua/UJRN/Nvkhdu_en_2019_34_3 (дата звернення: 08.08.2019).

2. Джулій В.M. Модель формування цілей інформаційного забезпечення підтримки процесів надання знань. Збірник наукових працьь Військового інституту Київського національного університету імені Тараса Шевченка. 2019. № 63. С. 85-95. URL: http://nbuv.gov.ua/UJRN/Znpviknu_2019_63_12 (дата звернення: 11.09.2019).

3. Карл Менгер. Основания политической экономии. URL: http://www.libertarium.ru/lib_mbv_menger (дата звернення: 28.10.2019).

4. Козловський Ю. Формування фахових знань майбутніх інженерів-педагогів комп’ютерного профілю: інтегративний підхід. Нова педагогічна думка. 2018. №1. С. 46-49. URL: http://nbuv.gov.ua/UJRN/Npd_2018_1_13 (дата звернення: 13.09.2019).

5. Кузнецова В. Китай. Финансовая бомба замедленного действия. Азия и Африка сегодня. 2015. № 10. C. 47.

6. Подлужна Н. О. Змістовна наповненість та проблематика інформаційного забезпечення формування економіки знань в Україні. Вісник Черкаського університету. Серія : Економічні науки. 2018. № 2. C. 102-111. URL: http://nbuv.gov.ua/UJRN/VchuE_2018_2_15 (дата звернення: 15.09.2019).

7. Сміт А. Історія економічних учень. URL: http://www.info-library.com.ua/books-text-1376.html (дата звернення: 28.10.2019).

8. Ханін І.Г., Поляков М.В., Білозубенко В.С. Про співвідношення концепцій економіки знань і цифрової економіки у формуванні нової парадигми розвитку світового господарства. Проблеми економіки. 2018. № 2. C. 38-43. URL: http://nbuv.gov.ua/UJRN/Pekon_2018_2_6 (дата звернення: 28.10.2019).

9. Dumas, Alexandre. The Count of Monte Cristo. Waiheke Island: Floating Press, 2009.

\section{References}

1. Busarieva, T.H. (2019). Spetsyfichni rysy formuvannia svitovoho rynku znan' [Specific Features of the Formation of the World Market of Knowledge]. Naukovyj visnyk Khersons'koho derzhavnoho universytetu. Ser.: Ekonomichni nauky - Scientific Bulletin of Kherson State University. Series: Economic Sciences, Vol. 34, 7-12. Retrieved from http://nbuv.gov.ua/UJRN/Nvkhdu_en_2019_34_3 [in Ukrainian].

2. Dzhulij, V.M. (2019). Model' formuvannia tsilej informatsijnoho zabezpechennia pidtrymky protsesiv nadannia znan' [Model of Formation of Goals of Information Support of Maintaining Processes for Providing Knowledge]. Zbirnyk naukovykh prats' Vijs'kovoho instytutu Kyivs'koho natsional'noho universytetu imeni Tarasa Shevchenka - Collection of Scientific Works of Taras Shevchenko Military Institute of Kyiv National University, 63, 85-95. Retrieved from http://nbuv.gov.ua/UJRN/Znpviknu_2019_63_12 [in Ukrainian].

3. Karl, Menger. (n.d.). Osnovanija politicheskoj jekonomii [Bases for Political Economy]. Retrieved from http //www.libertarium.ru/lib_mbv_menger [in Russian]. 
4. Kozlovs'kyj, Yu. (2018). Formuvannia fakhovykh znan' majbutnikh inzheneriv-pedahohiv komp'iuternoho profiliu: intehratyvnyj pidkhid [Formation of Professional Knowledge of Future Computer-Engineering Teachers: the integrative approach.]. Nova pedahohichna dumka - New pedagogical thought, 1, 46-49. Retrieved from http://nbuv.gov.ua/UJRN/Npd_2018_1_13 [in Ukrainian].

5. Kuznetsova, V. (2015). Kytaj. Fynansovaia bomba zamedlennoho dejstvyia [China. A Financial TimeBomb]. Azyia y Afryka sehodnia - Asia and Africa Today, 10, 47 [in Ukrainian].

6. Podluzhna, N.O. (2018). Zmistovna napovnenist' ta problematyka informatsijnoho zabezpechennia formuvannia ekonomiky znan' v Ukraini [Substantial Content and Problems of Information Support of Knowledge Economy Formation in Ukraine]. Visnyk Cherkas'koho universytetu. Seriia : Ekonomichni nauky - Bulletin of Cherkasy University. Series: Economic Sciences, 2, 102-111. Retrieved from http://nbuv.gov.ua/UJRN/VchuE_2018_2_15 [in Ukrainian].

7. Smit, A. (n.d.). Istoriia ekonomichnykh uchen' [History of Economic Thought]. Retrieved from http://www.info-library.com.ua/books-text-1376.html [in Ukrainian].

8. Khanin, I.H., Poliakov, M.V., \& Bilozubenko, V.S. (2018). Pro spivvidnoshennia kontseptsij ekonomiky znan' i tsyfrovoi ekonomiky u formuvanni novoi paradyhmy rozvytku svitovoho hospodarstva [On the Relation of Concepts of Knowledge Economy and Digital Economy in the Formation of a New Paradigm of Development of the World Economy]. Problemy ekonomiky - Problems of Economy, 2, 38-43. Retrieved from http://nbuv.gov.ua/UJRN/Pekon_2018_2_6 [in Ukrainian].

9. Dumas, Alexandre. (2009). The Count of Monte Cristo. Waiheke Island: Floating Press [in English].

Л.В. Кононенко, доц., канд. екон. наук

Центральноукраӥнський національний технічний університет, м. Кропивницький, Украйна

С.О. Кононенко, доц., канд. пед. наук

Центральноукраӥнський державний педагогічний університет імені Володимира Винниченка, м. Кропивнищький, Украӥна

B.I. Миценко, доц., канд. пед. наук

Центральноукрайнський національний технічний університет, м. Кропивницький, Украйна

\section{Формування фахових знань у випускників вищих навчальних закладів в умовах економіки знань: інтегративний підхід}

На сучасному етапі розвитку соціально-економічних відносин освіта грунтується на проблемному підході до змісту професійної підготовки, що обумовлює необхідність розвитку здатності сучасного випускника вищого навчального закладу розв'язувати комплексні завдання. Актуальність проведеного дослідження пов' язана з тим, що в умовах ринкової економіки робоча сила є товаром, i, як будьякий товар, вона підлягає продажу (оренді). Загальновідомо, що будь-який суб’єкт господарювання на ринку прагне отримати максимальний прибуток. Людина також є суб’єктом господарювання, яка прагне продати (здати в оренду) як найдорожче свою працю, вартість якої на ринку безпосередньо пов'язана із фаховими знаннями, вмінням їх використовувати тощо. На сьогодні залишається недостатньо вивченим та потребує подальших досліджень процес формування фахових знань у випускників вищих навчальних закладів в умовах економіки знань за інтегративним підходом.

Мета написання статті полягає в обгрунтуванні доцільності формування фахових знань випускників вищих навчальних закладів в умовах економіки знань за інтегративним підходом.

Обгрунтовано, що фундаментом для отримання знань людиною є освіта. У процесі навчання заклади освіти надають студенту «інформацію», яка у процесі навчання перетворюється на «знання». Ці «знання» змінюють індивідуума, який починає ними володіти. При цьому інформація $€$ «сировиною» для формування знань, а знання - це «якість», яка притаманна певному індивідууму. Процес набуття знань у вищих навчальних закладах достатньо складний. Саме інтегративний підхід до процесу формування фахових знань дозволить випускнику вищого навчального закладу мати конкурентні переваги на ринку праці в умовах економіки знань. Крім того, сформовані інтегровані знання дозволяють випускнику вищого навчального закладу на протязі всього свого життя оновлювати як отримані знання, так i формувати нові. Перспективи подальших досліджень у даному напрямі пов'язані із побудовою системи параметрів знань та їх зв'язків із метою цілісного підходу до формування фахових компетентностей випускників вищих навчальних закладів.

інформація, знання, фахові знання, економіка знань, інтеграція, інтегративний підхід, навчальні заклади, випускники вищих навчальних закладів 